\title{
FARMERS' MANAGEMENT CAPACITIES AS A SUCCESS FACTOR IN AGRICULTURE: A REVIEW
}

\author{
Nataša Vukelič ${ }^{1}$, Vesna Rodić
}

\begin{abstract}
Summary
Farms operating under more or less similar environmental and socio-economic conditions often reflect significant differences in production and economic results they achieve. Such differences are most commonly attributed to: biological factors, the level of specialization, the intensity of production, the size of farms and/or implemented production practice, etc. It is considered that the differences in achieved results, that is, the success of a farm can be, to a large extent, explained by variations in farmers' management capacities. Management capacities can be defined as possession of appropriate personal characteristics and capabilities of farmers (managers) to cope with specific problems and opportunities at the right time and in the right way.
\end{abstract}

With the changes taking place within the modern agricultural production, it is becoming more and more difficult to maintain competitive advantages, thus the farmers are progressively confronted with the requirements for certain management capacities which will enable them to take advantage of the existing conditions in the best possible way, i.e. to choose and implement the optimal production practice.

As the management capacities are rarely explicitly defined and quantified, particularly when it comes to agricultural producers, the aim of this study is to provide a review of the previous research in this field while highlighting the significance of these issues.

Key words: managerial capacities, farmer, agricultural production.

JEL: J24, J53, D79

\section{Introduction}

Good management is one of the key factors of success in all types of production, including agricultural. In order to be successful, i.e. to achieve successful and competitive

1 Nataša Vukelić, M.A., Assistant, University of Novi Sad, Faculty of Agriculture, Department of Agricultural Economics and Rural Sociology, Trg Dositeja Obradovića no. 8, 21000 Novi Sad, Serbia, Phone: +381214853992, E-mail: vukelicn@polj.uns.ac.rs

2 Prof. dr Vesna Rodić, Ph.D., Full professor, University of Novi Sad, Faculty of Agriculture, Department of Agricultural Economics and Rural Sociology, Trg Dositeja Obradovića no. 8, 21000 Novi Sad, Serbia, Phone:+381214853313, E-mail: rodicv@polj.uns.ac.rs

EP 2014 (61) 3 (805-814) 
production, farmers must dedicate much more of their time and pay much more attention when making management decisions, also in the process of development of management skills, as compared to their predecessors (Kay et al., 2008). Day after day, agricultural production is being developed and modernized, and there is higher degree of intensity and specialization, new technologies are being continuously adopted, production capacities are being expanded, investments into production process are being intensified, etc. All those factors create new management issues, but, at the same time, represent new opportunities for the farmers with adequate and high management capacities.

Farms operating under more or less similar environmental and socio-economic conditions often reflect significant differences in production and economic results they achieve. Such differences can be attributed to: biological factors, the level of specialization, the intensity of production, the size of farms, implemented production practice such as, for e.g., succession of crops and crop rotation, timely performance of specific operations, selection and implementation of appropriate fertilizers, pesticides and mechanization, adequate irrigation, storing methods, methods and conditions of placements of final products, etc. Many of these factors have been, and still are, the subject of great number of agronomic and agro-economic research studies. However, there is an issue which numerous empirical researches and literature have lately tried to explain, but which, on the other hand, has not been sufficiently researched, and it concerns the following: Why do certain farms have better utilization of resources at their disposal, as compared to the others? Why certain farms merge and get specialized, and others do not? Why do some farms implement higher and others lower level of intensity, and why do some of them implement practice which, in actual conditions, results in better production and economic results and others do not?

It is considered that the difference in achieved results, that is, the success of farms can, to a great extent be explained with differences in management capacities of farmers. Management capacities can be defined as "having the appropriate personal characteristics and skills to deal with the right problems and opportunities in the right moment and in the right way" (Rougoor et al., 1998; Rougoor, 1999; Trip, 2000).

As the management capacities are rarely explicitly defined and quantified, particularly when it comes to farmers, the aim of this study is to highlight significance of the said, to point out to the opportunities and the methods of their assessment, and to provide a review of the research activities conducted so far.

\section{Management capacities as a success factor in agriculture}

The significance of the human factor for success in agricultural production has been extensively studied. It is widely accepted in literature (Garforth, Rehman, 2005) that the initial theoretical and conceptual frameworks were established by Ashby, who was studying, far in 1930s, the behaviour and the motivation of farmers, and their influence on the management in production. Case and Johnston (1953) were observing management capacities even as the fourth factor of production, apart from three traditional factors such as soil, capital and the labour force. This was followed by research studies of distinguished agricultural economists 
Heady (1956), Johnson (1976) and Petrini (1970) were studying differences among the farmers, their motivations and behaviour.

The cutting edge in this field is the research study of Gasson (1973), who focused the attention to identification of drivers which farmers follow when making decisions. This was followed by numerous researches concerning the issue.

The research studies from earlier periods were mainly focused on influence of farmer personal (demographic) characteristics, such as age, education, gender, experience, etc., on production effectiveness. However, the accent is lately increasingly focused on decision making process. The authors, led by Rougoor et al. (1998), Trip (2000), as well as Johansson (2007), explain such approach with the fact that even the farmers having good personal characteristics can have unsatisfactory results if their decision making process is poor.

There are numerous studies worldwide in which the authors tried to explain the influences that certain aspects of management capacities have on success of farms, i.e. the effectiveness of the production - Ohlmer et al. (1998), Wilson et al. (1998 and 2001), Barkema et al. (1999), Solano et al. (2001a, 2001b and 2006), Trip et al. (2002), Passel et al. (2004), Adebayo, Adeola (2005), Mattil et al. (2007), Galanopoulos et al. (2006), Johansson (2007), Sharma et al. (1999), Sherif and Al-Kahtani (1999), to name but a few.

According to the authors' of this study knowledge, there are no studies concerning this topic in Serbia, at least not in the field of agriculture. There were some studies where authors analysed a variety of farmers' demographic characteristics (Novković et al., 2000) ${ }^{3}$ and/or emphasized importance of their capabilities/skills and quality of decision making process (Lazarević, 2006; Popović, 2008; Vukelić, Novković, 2009; Janković et al., 2010; Marković, Tomaš, 2010) ${ }^{4}$, but none of them has perceived the influences of the management capacities on effectiveness of agricultural production.

\section{Aspects of management capacities}

As mentioned above, management capacities can be defined “....as having the appropriate personal characteristics and skills to deal with right problems and opportunities in the right moment and in the right way."(Rougoor et al., 1998; Rougoor, 1999; Trip, 2000).

3 Novković et al. (2000) analysed, by perceiving the issue of possibility of development of agricultural production at the family farms, inter alia, the age and the educational structure of farmers.

4 Lazarević (2006) emphasized that a farmer have to be an educated businessman, ready to make decisions. Popović (2008) came to conclusion that some differences in business results among Serbian milk producers could not be explained other than as a difference in the quality of management. Vukelić and Novković (2009) variation in economic results of large milk producers in Vojvodina, operating under similar conditions, attributed to differences among farmers themselves, i.e. their capabilities and skills. Janković et al. (2010) insist on a new role of agricultural extension agents in the building of the farmers' capacities. Marković and Tomaš (2010) point out to the fact that the success of agricultural producers in the environment of severe competition, depends, among other, on their skills and knowledge.

EP 2014 (61) 3 (805-814) 
Personal characteristics and capabilities of farmers, as a very significant aspect of management capacities comprise of drivers and motivations, which include, for e.g. objectives that one farmer wants to achieve, their attitudes relating takeover of risks, etc., abilities and capabilities of farmers, such as, power of perception and intellectual skills, as well as biography of farmers which includes demographic characteristics and experience in specific production (Rougoor et al., 1998).

However, a farmer/manager with a good personal characteristics, will not always have guaranteed success if his decision making process is not good. That means that, when examining the influence of management capacities on achieved results, beside farmers' personal (demographic) characteristics, decision making process also have to be observed.

Farmers in general have the opportunity to make right business decisions, which will help them to achieve better results, by respecting well known steps in decision making process, such as planning, implementation and control. Kay et al. (2008) provide even more detailed division of decision making process, as follows:

1) Observing and defining the problem,

2) Collection of data and the information,

3) Finding and analysis of alternative solutions,

4) Decision making - choosing of the best alternative,

5) Execution (implementation) of decision,

6) Monitoring and analysis of the achieved results,

7) Taking responsibility for the decision.

Each of the listed steps requires from farmers/decision makers to precisely define priorities and timelines in decision making process, in order to avoid the stress caused by small and insignificant details, and which can lead to neglecting of important problems.

Rougoor and associates (1998) use very simple model to explain the relation between the management capacities, the environment, biological processes and the results achieved at the farm (Figure 1). 
Figure1. Model of management capacities in relation to environment, biological processes and farm results

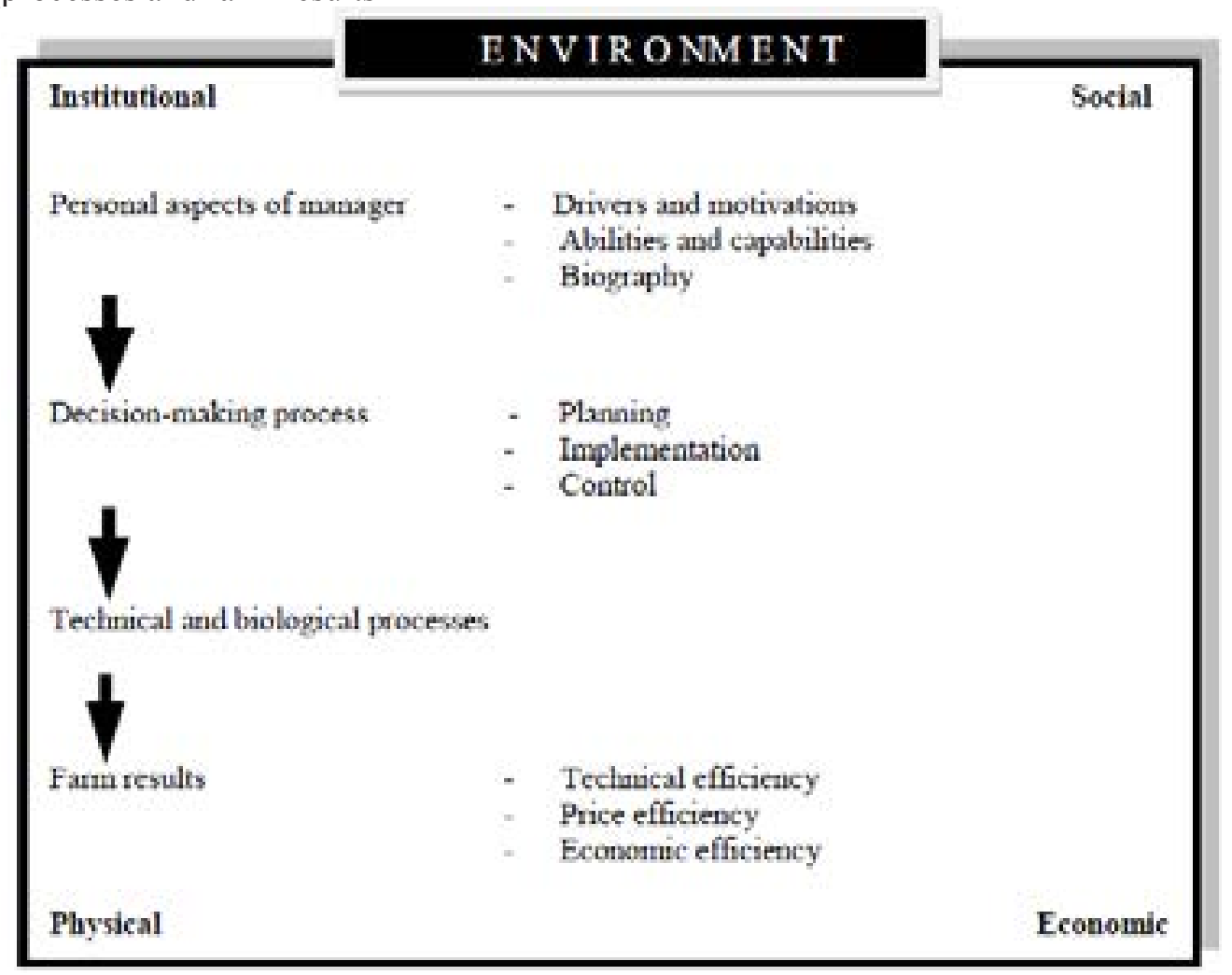

Source: Rougoor et al., 1998.

By respecting theirs, as well as the model given by Johansson $(2007)^{5}$, the aspects of management capacities and their influence on production and economic results can be presented in the following way (Figure 2).

Starting point is the farmer/manager, with specific personal characteristics. He tries, by appropriate business decisions, to optimize (or at least to influence) production and biological processes ${ }^{6}$, which determine production and economic results on the farm. There are many factors which influence the achieved results (weather conditions, various diseases, used pesticides, fertilizers, market fluctuations (prices), etc.). The risks and uncertainties in the decision making process increases, to a great extent, the fact that farmer/manager executes his tasks within the changing environment, where the direction of such changes is unpredictable.

5 Also focused on farmers' decision making process and its influence on the achieved results.

6 Which can be controlled only to a certain (limited) extent.

EP 2014 (61) 3 (805-814) 
Figure 2. The aspects of managerial capacities and their influence on farm results

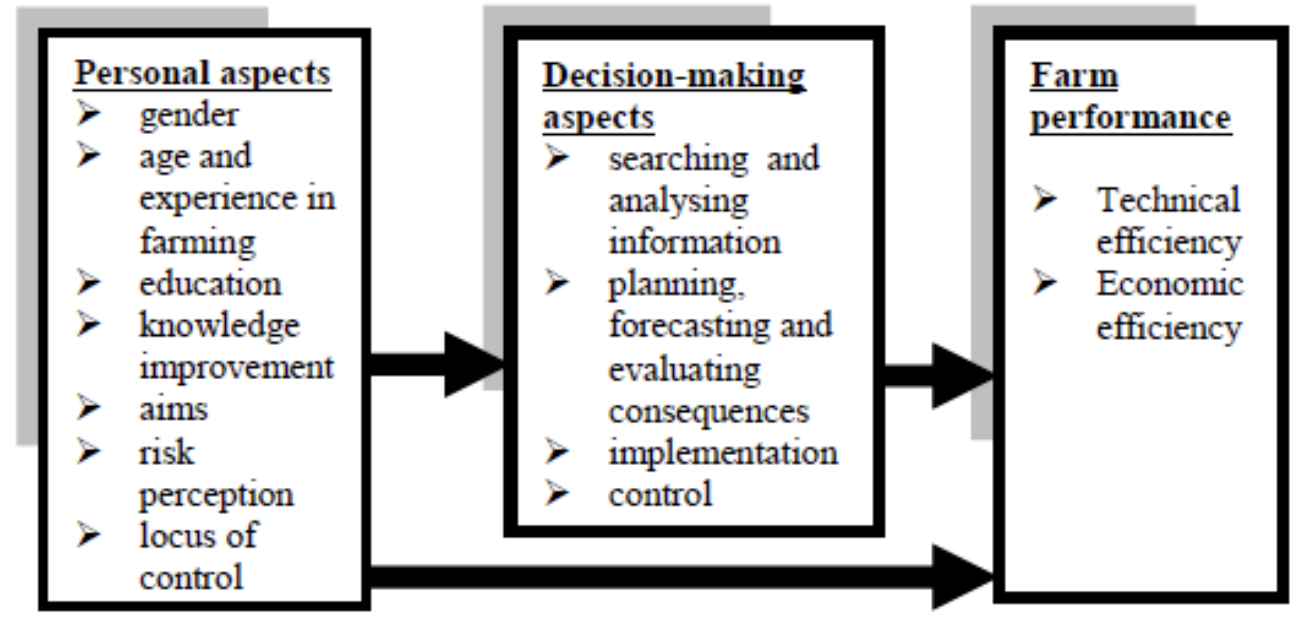

Source: Authors' compilation of two abovementioned models.

\section{Measuring managerial capacities issues}

Previous agricultural studies have observed that among the farms operating under more or less similar environmental and economic conditions, the differences in management capabilities lead to differences in achieved results. However, the deserved attention has not been paid to the management capabilities until recently. That is a direct consequence of complexity of their assessment. Nuthall (2009) explains this with the fact that the "people are difficult to be quantified".

The aspects of farmers' personal characteristics, such as the age, the education, and the experience in farming can be assessed relatively easy. On the other hand, drivers and motivations, as well as the abilities and the capabilities of farmers are much more difficult to observe and assess (Huirne et al., 1997).That is why decision making process, from the viewpoint of management capacities, has not been sufficiently examined. Given the fact that a manager is not able to divide the time necessary for planning, implementation and control it is very difficult to assess decision making process in an explicit way. Thus, these activities must be formulated in such a way to enable differentiation and assessment, for e.g., the frequency and duration of advisor's visits, time spent in the planning of own production, time spent on processing and analysis of the achieved results, time spent in the meetings with the farm-workers, farmer's notion about the results of the competitors, etc. (Mintzberg, 1973). Trip and associates (2002), also raise the question about assessment of quality of the decision making process. They claim that it can be quantified through the objectives and the production policy, the quality of planning, the quality of keeping records and monitoring, as well as the quality of self-evaluation. 


\section{Conclusion}

With the changes taking place within the modern agricultural production, it is becoming more and more difficult to maintain the competitive advantages. Thus, the farmers are progressively confronted with the requirements for certain management capacities which will enable them to utilise available resources in the best possible way, that is, to choose and implement the optimal production practice and to achieve best possible results.

Although management capacities are still rarely explicitly defined and quantified, especially when it comes to farmers, there are plenty of studies where authors analyse both personal characteristics of farmers and their decision making process, as well as their influence on the farm success.

Unfortunately, there is a lack of such research in Serbia. One can expect that the management capacities will be the significant field of research in the future, since their improvement is a precondition for improvement of competitiveness of Serbian agricultural production urgently needed in the process of European integration.

\section{Acknowledgment}

This paper is a result of the research within the projects III 31033 and III 046012, financed by the Ministry of Education, Science and Technological Development, Republic of Serbia.

\section{Literature}

1. Adebayo, O. O., Adeola, R. G. (2005): Socio-Economics Factors Affecting Poultry Farmers in Ejigbo Local Government Area of Osun State, Journal Human Ecology, Vol. 18, no. 1, pp. 39-41.

2. Barkema, H. W., Van der Ploeg, J. D., Schukken, Y. H., Lam, T. J. G. M., Benedictus, G., Brand, A. (1999): Management style and its association with bulk milk somatic cell count and incidence rate of clinical mastitis, Journal of Dairy Science, no. 82, pp. 1655-1663.

3. Case, H. C. M, Johnston, P. E. (1953): Principles of farm management, Chicago, etc.: J. B. Lippincott Company.

4. Garforth, C., Rehman, T. (2005): Review of literature on measuring farmers'values, goals and objectives, Project report no.2, available at: https://statistics.defra.gov.uk/esg/ reports/Farmer\%20Behaviour/...

5. Gasson, R (1973): Goals and values of farmers, Journal of Agricultural Economics, no. 24, pp. 521-542.

6. Galanopoulos, K., Aggelopoulos, S., Kamenidou, I., Mattas, K. (2006): Assessing the effects of managerial and production practices on the efficiency of commercial pig farming, Agricultural Systems, vol. 88, pp. 125-141

7. Heady, E. O. (1956): The basic logic farm and home planning, Journal of Farm Economics, no. 38 , pp. 80-92.

8. Huirne, R. B. M., Harsh, S. B., Dijkhuizen, A. A. (1997): Critical success factors and 
information needs on dairy farms: the farmer's opinion, Livestock Production Science, no. 48 , pp. $229-238$.

9. Janković, D., Petrović, Ž., Čikić, J. (2010): Karakteristike savetodavnog procesa u radu sa odabranim gazdinstvima u Vojvodini, Ekonomika poljoprivrede, vol. LVII, no. 2, pp. 257-273.

10. Johansson, H. (2007): How can farmer managerial capacity contribute to improved farm preformance? A study of dairy farms in Sweden, American Agricultural Economics Association Annual Meeting, Portland, OR, July 29 - August 1, available at: www. ageconsearch.umn.edu/bitstream/9874/1/sp07jo03.pdf

11. Johnson, G. L. (1976): Philosophic foundations: problems, knowledge and solution, European Review of Agricultural Economics, no. 3, pp. 207-234.

12. Kay, R. D, Edwards, W. M., Duffy, P. A. (2008): Farm Management, $6^{\text {th }}$ Edition, McGraw Hill, Higher Education.

13.Lazarević, R. (2006): Kako brže do profitabilnog stočarstva, Vizartis, Beograd.

14. Marković, K., Tomaš, M. (2010): Zakonodavno - pravini okvir kao jedan od uslova za razvoj poljoprivrednog savetodavstva, Agroekonomika, br. 45-46, vol. 45-46, pp. 61-68.

15. Mattila, E., Tiina, A., Kaustell, O. K., Leppala, J., Hurme, T., Suutarinen, J. (2007): Farmers' Perceptions of Necessary Management Skills in Finland, The Journal of Agricultural Education and Extension, Vol. 13, no. 4, pp. 287-300.

16. Mintzberg, H. (1973): The nature of managerial work, New York, Harper \& Row.

17. Novković, N., Ceranić, S., Bogdanov, N., Rodić, V. (2000): Possibilities of agricultural production development at the family farms in Yugoslavia, $70^{\text {th }}$ EAAE seminar Problems and Prospects of Balkan Agriculture in a Restructuring Environment, Thessaloniki, Greece, pp. 97-104.

18. Nuthall, P. (2009): Modelling the origins of managerial ability in agricultural production, The Australian Journal of Agricultural and Resource Economics, Vol. 53, no. 3, pp. 413436.

19. Öhlmér, B., Olson, K., Brehmer, B. (1998): Understanding farmers' decision making processes and improving managerial assistance, Agricultural Economics, no.18, pp. 273-290.

20. Passel, V. S., Lauwers, L., Huylenbroeck, V. G. (2004): Factors of farm performance: an empirical analysis of structural and managerial characteristics, Chapter 1, available at: www.fat.admin.ch/eaae96/abstracts/s23.pdf

21.Petrini, F. (1970): The goals of farmers - A pilot study, Supplement to International Journal of Agrarian Affairs, no.5, pp.175-184.

22. Popović, R. (2008): Uticaj ekonomije veličine u proizvodnji mleka na komercijalnim porodičnim gazdinstvima u Srbiji, Biotechnology in Animal Husbandry, $18^{\text {th }}$ Symposium on Innovation in Animal Science and Production, Faculty of Agriculture, University of Belgrade, Institute of Zoo-technology, Belgrade, pp. 609-618. 
23. Rougoor, C. W, Trip, G., Huirne, R. B. M, Renkema, J. A. (1998): How to define and study farmers' management capacity: theory and use in agricultural economics, Agricultural Economics, no. 18, pp. 261-272.

24. Rougoor, C. W. (1999): Management, milk production level and economic performance, An explorative study on dairy farms, $\mathrm{Ph} . \mathrm{D}$. - thesis, Wageningen University.

25. Sharma, K. R., Leung, P., Zaleski, H. M. (1999): Technical, allocative and economic efficiencies in swine production in Hawaii: a comparison of parametric and nonparametric approaches, Agricultural Economics, no. 20, pp. 23 - 35.

26. Sherif, S. A., Al Kahtani, S. H. (1999): Managerial efficiency under risk for broiler producers in Saudi Arabia, Agricultural Economics, no. 20, pp.69- 74.

27. Solano, C., Leon, H., Perez, E., Herrero, M. (2001b): Characterising objective profiles of Costa Rican dairy farmers, Agricultural Systems, no. 67, pp. 153-179.

28. Solano, C., Leon, H., Perez, E., Herrero, M. (2001a): Who makes farming decisions? A study of Costa Rican dairy farmers, Agricultural Systems, no. 67, pp. 181-199.

29. Solano, C., Leon, H., Perez, E., Tole, L., Fawcett, R.H., Herrero, M. (2006): Using farmer decision-making profiles and managerial capacity as predictors of farm management and performance in Costa Rican dairy farms, Agricultural Systems no. 88, pp. 395-428.

30. Trip, G. (2000): Decision making and economic performance of flower producers, Ph.D. - thesis, Wageningen University.

31. Trip, G., Thijssen, G. J., Renkema, J. A., Huirne, R. B. M. (2002): Measuring managerial efficiency: the case of commercial greenhouse growers, Agricultural Economics, no. 27 , pp. 175-181.

32. Vukelić, N., Novković, N. (2009): Ekonomski rezultati proizvodnje mleka na krupnim seljačkim gazdinstvima, Ekonomika poljoprivrede, no. 2009/1, Beograd, pp. 99-110.

33. Wilson, P., Hadley, D., Ramsden, S., Kaltsas, I. (1998): Measuring and explaining technical efficiency in UK potato production, Agricultural Economics, no. 49, pp. 294-305.

34. Wilson, P., Hadly, D., Asby, C. (2001): The influence of management characteristics on the technical efficiency of wheat farmers in eastern England, Agricultural Economics, no. 24, pp. 329-338. 


\title{
MENADŽERSKI KAPACITETI FARMERA KAO FAKTOR USPEŠNOSTI POLJOPRIVREDNE PROIZVODNJE
}

\author{
Nataša Vukelič , Vesna Rodič ${ }^{8}$
}

\begin{abstract}
Rezime
Između farmi koje posluju u manje-više sličnim prirodnim i društveno-ekonomskim uslovima često postoje veoma značajne razlike u proizvodnim i ekonomskim rezultatima koje one postižu. Te razlike se najčešće mogu pripisati: biološkim faktorima, nivou specijalizacije $i$ intenzivnosti proizvodnje, veličini farme i/ili proizvodnoj praksi koja se na farmi primenjuje. Smatra se da se razlike u postignutim rezultatima, tj. uspešnosti farme, mogu u velikoj meri objasniti i razlikama u sposobnostima samih farmera, odnosno njihovim menadžerskim kapacitetima, koji se mogu definisati kao posedovanje odgovarajućih ličnih karakteristika $i$ sposobnosti farmera, odnosno menadžera, da se suoče sa određenim problemima $i$ mogućnostima na pravi način i u pravom trenutku.

Sa promenama koje zahvataju savremenu poljoprivrednu proizvodnju, sve je teže održavati konkurentsku prednost, pa farmeri sve više moraju imati određene menadžerske kapacitete koji će im omogućiti da, na najbolji mogući način, iskoriste raspoložive uslove, odnosno odaberu i primene optimalnu proizvođačku praksu. Menadžerski kapaciteti se dosta retko ekspicitno definišu i kvantifikuju, posebno kada su poljoprivredni proizvođači u pitanju, stoga je cilj ovog rada upravo da ukaže na značaj menadžerskih kapaciteta farmera i da da pregled dosadašnjih istraživanja u ovoj oblasti.
\end{abstract}

Ključne reči: menadžerski kapaciteti, farmeri, poljoprivredna proizvodnja.

7 Nataša Vukelić, M.A., asistent, Univerzitet u Novom Sadu, Poljoprivredni fakultet, Departman za ekonomiku poljoprivrede i ruralnu sociologiju, Trg Dositeja Obradovića 8, 21000 Novi Sad, Srbija, Telefon: +381 2148539 92, E-mail: vukelicn@polj.uns.ac.rs

8 Prof. dr Vesna Rodić, Redovni profesor, Univerzitet u Novom Sadu, Poljoprivredni fakultet, Departman za ekonomiku poljoprivrede i ruralnu sociologiju, Trg Dositeja Obradovića 8, 21000 Novi Sad, Srbija, Telefon: +381 2148533 13, E-mail: rodicv@polj.uns.ac.rs 